\title{
Sustainable Level Debt, Expansionary Austerity, and Fiscal Consolidation Theories: A Critical Analysis
}

\author{
Muhamed Zulkhibri \\ Senior Economist, Islamic Research and Training Institute \\ Islamic Development Bank, Jeddah, Saudi Arabia
}

\begin{abstract}
This commentary critically analyzes the debate between 'deficit financing' and 'deficit-reduction financing' in contemporary economics. Reading through the paper by Ann Pettifor (2019), one gets the impression that deficits don't matter and that fiscal consolidation has not improved the public finances, at least for the advanced economies. Although Pettifor manages to pinpoint some of the fundamental errors in contemporary economic discussions on deficit financing, her paper puts undue emphasis on Keynes's approach to public spending. Keynes's argument was that increases in government spending will improve growth by boosting purchasing power into the economy. However, she fails to notice the basic problem with debt, that it keeps countries from investing in future growth. A more fundamental question to this debate should be to address the issues surrounding the sustainability of debt and the most effective means to reduce debt to sustainable levels. Therefore, fiscal restraint should be taken as an opportunity to make an economic virtue out of fiscal necessity, not to be politicized by politicians and policymakers to increase unnecessary and wasteful government spending that would expose countries to a higher degree of economic vulnerability.
\end{abstract}

Keywords: Deficit financing, Budget deficit, Government spending, Fiscal consolidation.

JEL Classification: E62, H30, H50, H62, H63

KAUJIE Classification: R72, R73, R81, R82 


\section{Introduction}

Pettifor's paper (2019) is a welcome initiative by the learned author who sees a fundamental error in contemporary economic discussions on deficit financing. Her assessment of the recent situation has led her to conclude: "Fiscal consolidations have not improved the public finances" and that "attempts to lower the debt ratio by cutting spending has always been counterproductive" (Pettifor, 2019, p. 67). Pettifor is critical of how the government handles public finances in a simplistic way. She argued that "[s]ustained, fiscal consolidation increases rather than reduces the public debt ratio and is, in general, associated with adverse macroeconomic conditions" (Pettifor, 2019, p. 67). In her view, the fundamental flaws are: (i) "the microeconomic approach that treats government budget deficits in much the same way as a household deficit", and (ii) the approach ignores "evidence that government deficits, and a rise in public debt, are most often the consequence of a slump - a fall in economic activity ('growth') and, therefore, of a fall in government revenues" (Pettifor, 2019, p. 67).

One of the fundamental questions in growth theory is whether increasing government spending promotes economic growth. It has been an on-going issue in debates among policymakers. Supporters of government spending looked to the thinking of John Maynard Keynes. They advocate that government spending provides public goods that markets generally do not, such as, education and infrastructure. They also claim that increases in government spending by putting money into people's pockets can bolster economic growth. On the other hand, advocates of lower government spending have a differing view that higher spending, by transferring additional resources less efficiently from the productive sector of the economy to the government, weakens economic growth. If the expansion of government spending induces higher taxes and/or borrowing to finance the expenditures, it may constraint overall economic performance.

Since servicing debt will become a major burden, economies can either raise taxes or lower spending to reduce debt. The concern about debt is that it may hinder countries from investing in future growth. What are the most effective means to reduce debt to sustainable levels? This question has taken on renewed importance since the global financial crisis of 2008, and when governments in many advanced economies want to increase spending to stimulate growth. Therefore, some economists argue that fiscal austerity is essential to return to debt sustainability. Large public debt fuels concerns on fiscal sustainability and makes the economy less resilient to shocks. Hence, reducing public debt and correcting fiscal imbalances have become high priorities. Others insist that spending cuts are self-defeating, because they hurt economic growth and point to the experience of financial repression after World War II. They propose even more government spending to bolster an abating economy.

From a general policy standpoint, existing evidence points to the importance of reducing high public debt to restore fiscal sustainability and support stronger fundamentals. There has been a recent series of research arguing for the growth benefits from fiscal adjustments. Harvard University economist Alberto Alesina, has written papers over the last two decades professedly showing that fiscal adjustments can be expansionary even in the short-run, the doctrine of 'expansionary austerity'. The theory of expansionary austerity takes part to a long-standing debate in economic literature on the effectiveness of fiscal policy (Alesina \& Perotti, 1995; Alesina, Ardagna, \& Trebbi, 2006). In the words of Jonathan Portes:

the UK Treasury [noted] in the 2010 Emergency Budget that: "These [the wider effects of fiscal consolidation] will tend to boost demand growth, could improve the underlying performance of the economy and could even be sufficiently strong to outweigh the negative effects". (Portes, 2012, para 7; quotation marks in original)

In April (2010), in Madrid, Alesina told the European Union's economic and finance ministers that "large, credible and decisive" spending cuts to rescue budget deficits have frequently been followed by economic growth (Coy, 2010, para 2). He claimed to find evidence that spending cuts were often "associated with economic expansions rather than recessions", i.e., Alesina's golden rule (Alesina \& Ardagna, 2010, p. 37; Kunieda, 2015, p. 304, footnote). Moreover, his work suggested that spending cuts create confidence, and that the positive effects of an increase in 
confidence outpace the direct negative effects of reduced spending (Alesina, Favero, \& Giavazzi, 2012). However, his basic argument is not always applicable to all economies.

Is there unambiguous evidence of expansionary fiscal austerity? Some economists stated that, at least under certain conditions, discretionary expansionary fiscal policies are not normally suitable for demand management and prove to be ineffective to stimulate economic activity. At the same time, such policies may put at risk the strength of public finances and of the whole financial system of the economy (Alesina \& Ardagna, 2012; see also Sutherland, 1997, for the case of possible non-Keynesian effects of expansionary fiscal measures when undertaken in a context of high public debt). In summary, Alesina merely demonstrates that in some cases, it is difficult to ascertain a contractionary impact of fiscal austerity. As Alesina notes, "sometimes, not always, some fiscal adjustments based upon spending cuts are not associated with economic downturns" (Alesina, 2010,2 nd last para). It is very unfortunate that such a modest assertion made by the author has been overlooked by the supporters of fiscal consolidation and, at times, even by the critics (Romer, 2011, pp. 1718). Hence, the findings of Alesina and his collaborators echo so strongly with at least some policy makers because of an ideological repugnance to countercyclical fiscal policy.

\section{The Myths of Keynesian Stimulus}

In Pettifor's analysis, she argued that

if policy-makers pursued the policies advocated in his General Theory by John Maynard Keynes, then we could expect a revival of 'the golden age' of economics inflation in the late 1910s and 1970s which were not periods of rapid debt reduction. (Pettifor, 2019, p. 67)

She also put forward the misunderstanding of Keynes's approach to public spending as 'deficit spending' rather than 'deficit-reduction spending'. For her, this reflects a serious misunderstanding of Keynes's idea that the main purpose of increasing loan-financed government spending at times of economic weakness is to increase the nation's income (p. 67). In fact, the entire paper is based on Keynes's macroeconomics proposition that an expansionary fiscal policy will lead to growth in activity and employment, so that, with spare capacity, high government spending reduces the deficit. In supporting, she assumes that "[i]ncreased production means increased incomes, which, from the point of view of government, means higher tax revenues and lower welfare (and, later, debt interest) expenditures" (Pettifor, 2019, p. 67).

Deficits and debt have always been prominent debates around Keynesian economics. Keynes's economic policy thought on the role of public debt is always a question of great interest. John Maynard Keynes's 1936 book, The General Theory of Employment, Interest, and Money, argued that increases in government spending enhance growth by boosting purchasing power into the economy. However, the theory has since fallen out of favor, but it still influences policy discussions, particularly on whether or not changes in government spending have transitory economic effects. It is understandable that Keynesianism receives many politicians' applause because it provides a rationale for spending more money or more precisely, spending other people's money. Keynesian theory is an unintended gift from some economists to politicians. Many inexperienced politicians upon seeing businesses closing up and workers being laid off, conclude that the problem is inadequate spending. But they fail to acknowledge the fact that government cannot inject money into the economy without 'crowding out' the private sector via taxes and borrowing.

Keynes's position on counter-cyclical fiscal policy was not, by way of recourse to deficit spending, to prevent macroeconomic fluctuations, but rather by supporting a full employment policy through a permanent public expansionary expenditure, with an emphasis on public investment. He argued that government spending should be reduced once the economy recovered to prevent inflation, which in turn generates too much economic growth. Some economists even suggested that there was a trade-off between inflation and unemployment (the Phillips Curve) and that government should navigate the economy by increasing or decreasing public spending. By 'deficit financing' Keynes means an excess of recurrent spending over recurrent revenues. He also intended debt issued for public capital expenditure to be partly serviced by user charges (Keynes, 1978, vol. 27, pp. 224-225, 319-320, 405-406). 
Moreover, Keynes argued that aggregate demand is not stable, it can change unexpectedly. Keynes once said that "the national debt can't keep on growing" (Colander \& Landreth, 1996, p. 109). It is vividly clear that Keynes's policy deliberations endorse as a general principle (but not completely inflexible), that public debt should be used only to finance capital expenditures (for factual-based interpretations of Keynes's general position on fiscal policy, in the framework of current versus capital budgeting, see: Kregel, 1985; Brown-Collier \& Collier, 1995; and Clarke, 1998). Nevertheless, the conventional characterization of 'Keynesian' economic policy has broken many of the links with Keynes's work itself.

\section{Deficits Don't Matter}

Pettifor argues that deficits don't matter. It is based on the approach adopted mostly by Modern Monetary Theorists (MMT) that perpetual government budget deficits are both necessary and unproblematic. Government spending, it is argued, can be financed almost ad infinitum by a central bank that has the exclusive power to 'print' or create fiat currency. It is related to the accounting identity methodology: Domestic Private Surplus = Government Budget Deficit. Hence, we need to distinguish between government (i.e. monetarily sovereign government) and household finances (i.e. those that lack such sovereign status). For every surplus, it is argued that there has to be a deficit and vice-versa. Therefore, to ensure the private sector remains in surplus, MMTs conclude that the government must not reduce its deficit. It is true that current government spending is not limited by taxation or borrowing but by inflation risk. The costs of excessive public expenditure are felt instantaneously in the form of inflation and are not borne by future generations.

On the other hand, we have been told that government debt is finite. In issuance of government debt, there is an absolute limit to the amount of debt. The government will default if it exceeds that absolute limit. Persistently running deficits mean that at some point, the worried about default trigger will be reached and the government will default. Therefore, governments must observe fiscal discipline and avoid excessive deficits. Even if default is avoided, the cost of servicing debt will be unaffordable for future generations. Even at the expense of much needed investment, the moral imperative is to close deficits and cut debt. Because high public debt is perceived to be so dangerous, politicians - especially in Europe have given a higher priority to closing public deficits. In the words of Kajal Lahiri, an economics professor at the University at Albany, "[deficits] certainly matter, and they matter in a bad, undesirable way" (Freedman, 2018, para 8).

The key to this debate is the sustainability of debt. Sustainable debt models suggest that the government will run a primary surplus sufficient to pay back all the debt over a defined time horizon. But governments in a strong fiscal position generally don't repay debt, they refinance it. What really matters is the debt service cost. Debt interest must be comfortably payable from current income to be sustainable. If the interest rate is equal to or less than the growth rate of nominal gross domestic product, public debt is sustainable indefinitely. However, some economists argue that budget deficits are bad because they purportedly lead to higher interest rates. Since higher interest rates reduce investment, and because investment is necessary for long-term economic growth, advocates of this view state that avoiding deficits should be the primary goal of fiscal policy.

\section{Deficit Financing}

Academic interest in deficit financing is not new. One of the most debatable, and repeatedly cited by policy makers, was the paper published by Reinhart and Rogoff in 2010. They claimed that there was a red line for debt at $90 \%$ of GDP and when external debt reaches $60 \%$ of GDP, annual growth declines by about two percent (Reinhart \& Rogoff, 2010, p. 573). This finding was used repeatedly by policy makers. Unfortunately, Pettifor discredited Reinhart and Rogoff when the paper was later cited by both Republicans, British Conservatives, and European officials to argue for cuts in government spending by quoting the words of John Cassidy that "how seriously should we take any economist's policy prescriptions, especially ones that are seized upon by politicians with agendas of their own" (Pettifor, 2019, p. 67). She seems to condemn the advocates of austerity policy as if all of the economic researches aligned with austerity push have been discredited in the history of economic debates. 


\section{Fiscal Consolidation}

Fiscal consolidation is a policy aimed at reducing government budget deficits and debt accumulation, and its objective can be achieved through either reducing government spending or increasing government receipts, such as through tax increases, higher user fees and/or asset sales. The theory of 'Ricardian equivalence' asserts that funding government spending through means of a deficit (or increased debt) is not likely to stimulate the economy as households recognize that they are only going to be required to pay this additional spending back at a time in the future. This results in those non-credit constrained households increasing their savings by an amount equivalent to the additional government spending, resulting in no net increase in demand in the economy (and vice versa). That is, under normal conditions, the management of a country's budget into a deficit will not stimulate economic growth, and conversely, the implementation of a policy of fiscal consolidation will not trigger an economic slowdown. However, Keynes suggested that 'Ricardian equivalence' does not hold universally, especially in those periods where households are concerned about their future prosperity and when credit is limited.

Another exception to 'Ricardian equivalence' occurs where public debt is so high that it attracts a significant premium for default risk or inflation. A credible government policy of fiscal consolidation targeting a country's debt and deficit position could be viewed positively by capital markets, resulting in a reduction in the interest rate premium and a consequent stimulation of business investment. That is, when a country accumulates too much debt, or is operating with an unsustainably high budget deficit, then economic growth is retarded. By implementing fiscal consolidation programs, a country's debt and deficit position becomes more controllable, interest costs become lower, and growth accelerates. A fiscal consolidation strategy would be welcomed by debt markets, thus increasing agents' confidence in the government's capacity to solve the crisis. JeanClaude Trichet, the former European Central Bank President once said: "I firmly believe that in the current circumstances, confidence-inspiring policies will foster and not hamper economic recovery, because confidence is the key factor today" (Hughes, 2010, para 4).

For households, fiscal consolidation programs that cut government spending, reduce consumer uncertainty about taxes, both in the short- and longer-term. This creates expectations for higher disposable income, generating a positive wealth effect, resulting in increased demand for durable and non-durable goods. For fiscal consolidation programs that result in increased taxes, households not only spend less on consumption goods and services (as the post-tax wage has fallen), but they also spend less on durable goods as their future income expectations are scaled back. However, one should not attribute such results (growth and employment creation) of fiscal consolidation programs to fiscal austerity alone. There are often complementary factors at work that might be more important than fiscal actions. They include: (i) the influence of the global and regional business cycle, (ii) monetary policy, (iii) exchange rate policy and (iv) structural reforms. The best time to implement a fiscal austerity program is during a boom rather than a slump.

\section{Conclusion}

In my view, we are in danger of making a false economic policy because our judgment is clouded by common misconceptions about the government's stimulus programs. Fiscal restraint should be viewed as an opportunity to make an economic virtue out of fiscal necessity. This debate is sometimes vitiated by ideological elements that make a rational economic discussion difficult. Although the deficit is not the critical variable, the need to reduce spending would still exist. Since there are many wasteful spending programs, it is essential to set priorities of public spending by cutting existing wasteful spending and prevent new unnecessary spending policies. No analysis, whether pure research or policy related, can include everything that might possibly be relevant. The economy will only benefit if government spends money in a productive way that generates an adequately high rate of return. 


\section{References}

Alesina A., \& Ardagna, S. (2012). The Design of Fiscal Adjustments (NBER Working Paper No. 18423). Retrieved from: https://www.nber.org/papers/w18423 .pdf

Alesina, A. (2010). My answer to The Economist. Retrieved from: https://scholar.harvard.edu/alesina/ content/my-answer-economist

Alesina, A., \& Ardagna, S. (2010). Large Changes in Fiscal Policy: Taxes versus Spending. In J. R. Brown (Ed.), Tax Policy and the Economy: Vol. 24 (pp. 3568). Chicago, USA: University of Chicago Press. Retrieved from: https://www.nber.org/books/brow09-1

Alesina, A., \& Perotti, R. (1995). Fiscal Expansions and Fiscal Adjustments in OECD Countries (NBER Working Paper No. 5214). Retrieved from: https:// www.nber.org/papers/w5214.pdf

Alesina, A., Ardagna, S., \& Trebbi, F. (2006). Who Adjusts and When? The Political Economy of Reform. IMF Staff Papers, 53(Special Issue), 1-49. Retrieved from: https://www.jstor.org/stable/pdf/30036020.pdf

Alesina, A., Favero, C., \& Giavazzi, F. (2012). The Output Effect of Fiscal Consolidations (NBER Working Paper No. 18336). Retrieved from: https:// www.nber.org/papers/w18336.pdf

Brown-Collier, E.K., \& Collier, B.E. (1995). What Keynes Really Said about Deficit Spending. Journal of Post Keynesian Economics, 17(3), 341-355.

Clarke, P. (1998). Keynes, Buchanan, and the BalancedBudget Doctrine. In J. Maloney (Ed.), Debt and Deficits: An Historical Perspective (pp. 60-83). Cheltenham, UK: Edward Elgar.

Colander, D.C., \& Landreth, H.H. (eds.). (1996). The Coming of Keynesianism to America: Conversations with the Founders of Keynesian Economics. Cheltenham, UK: Edward Elgar.

Coy, P. (2010, July 1). Keynes vs Alesina. Alesina Who? Economist Alberto Alesina argues that austerity triggers growth. Bloomberg BusinessWeek. Retrieved from: https://www.bloomberg.com/news/articles/201006-29/keynes-vs-dot-alesina-dot-alesina-who

Freedman, D. (2018, February 16). GOP, Dems agree: Deficits don't matter until they do. Timesunion. Retrieved from: https://www.timesunion.com/7daystate/article/GOP-and-Dems-agree-Deficits-don-tmatter-until-12620439.php
Hughes, K. (2010, June 24). ECB's Trichet says susterity plans don't risk stagnation. Reuters, Business News. Retrieved from: https://www.reuters.com/article/usecb-trichet/ecbs-trichet-says-susterity-plans-dont-riskstagnation-idUSTRE65N17O20100624

Keynes, J.M. (1964). The General Theory of Employment, Interest, and Money. San Diego, California, USA: HBJ Publishers. (Original work published 1936)

Keynes, J.M. (1978). The Collected Writings of John Maynard Keynes (D. E. Moggridge \& E. S. Johnson, Eds.). London, UK: Cambridge University Press for the Royal Economic Society.

Kregel, J.A. (1985). Budget Deficits, Stabilisation Policy and Liquidity Preference: Keynes's Post-War Policy Proposals. In F. Vicarelli (Ed.), Keynes's Relevance Today (pp. 28-50). London, UK: Palgrave Macmillan.

Kunieda, S. (2015). Is Alesina's Argument on the TaxSpending Mix in Fiscal Consolidation Applicable to Japan? Policy Research Institute, Ministry of Finance, Japan, Public Policy Review, 11(2), 303332. Retrieved from: https://www.mof.go.jp/english/pr i/publication/pp_review/ppr028/ppr028d.pdf

Pettifor, A. (2019). 'Deficit Financing' or 'DeficitReduction Financing?' Debates in Contemporary Economics: Origins, Confusions and Clarity. Journal of King Abdulaziz University: Islamic Economics, 32(1), 67-78.

Portes, J. (2012, February 7). Fiscal policy: What does 'Keynesian' mean? Retrieved from: https://voxeu.org/ article/what-does-keynesian-really-mean

Reinhart, C.M., \& Rogoff, K. (2010). Growth in a Time of Debt. American Economic Review, 100(2), 573-578.

Romer, C. (2011). What Do We Know About the Effects of Fiscal Policy: Separating Evidence from Ideology [Pdf file]. Retrieved from: https://eml.berkeley.edu/ cro mer/Lectures/Written\%20Version\%20of\%20Effects\% 20of\%20Fiscal\%20Policy.pdf

Sutherland, A. (1997). Fiscal Crises and Aggregate Demand: Can High Public Debt Reverse the Effect of Fiscal Policy? Journal of Public Economics, 65(2), 147-162. 
Muhamed Zulkhibri is a Senior Economist at the Islamic Research and Training Institute, Islamic Development Bank (IRTI, IDB), Saudi Arabia. Prior to joining IRTIIDB, he worked at the Central Bank of Malaysia and a policy research institution in various capacities. He has been involved in many task forces, training and research, spoke at various conferences/workshops, and has provided advisory/consulting services to various organizations worldwide. Previously, he lectured at the University Putra Malaysia, and the University of Nottingham, United Kingdom. His current research focuses on monetary economics, macroeconomics and economic development, and Islamic banking and finance. He has published extensively in various publications in leading academic journals, industry reports, books, and the financial press. His most recent books include Macroprudential Regulation and Policy for Islamic Financial Industry (Springer, 2016); and Financial Inclusion and Poverty Alleviation: Perspectives from Islamic Institutions and Instruments (Palgrave, 2017). He is the co-editor of the Islamic Economic Studies journal. He earned a $\mathrm{PhD}$ in economics from the University of Nottingham, United Kingdom.

E-mail: khibri1974@yahoo.com 


\title{
العجز الحكومي المستدام ونظريات التقشف التوسعي والدمج المالي: تحليل نقدي
}

\author{
محمد ذو الخبري

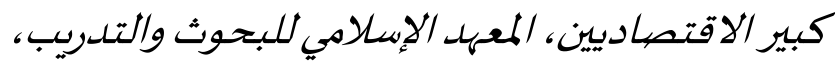

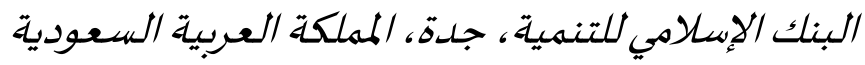

المستخلص. تطرح هذه الورقة تحليلا ناقدا للجدل القائم بين تمويل العجز وتمويل خفض العجز في الاقتصاد المعاصر. ويمكننا أن نستشف من ورقة آن بيتيفور (2019م) بأن العجز ليس له أهمية

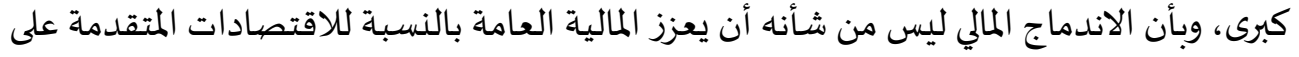

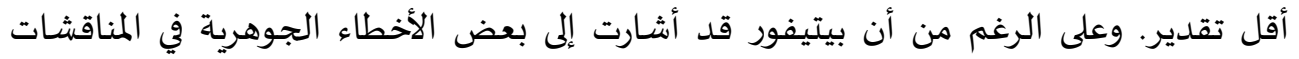

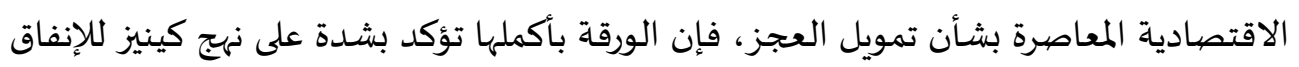

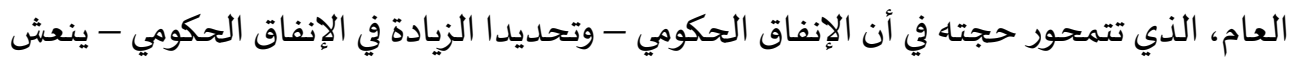
النمو من خلال دعم القوة الشرائية في الاقتصاد. وعلى الرغم من ذلك، فقد فشلت الباحثة في

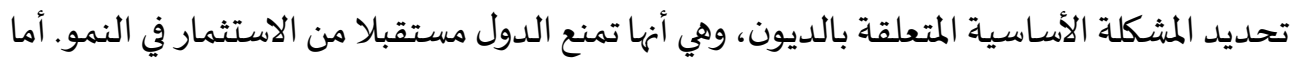
السؤال الأكثر جوهرية في هذا النقاش فيتمثل في القضايا ذات العلاقة بالقدرة على تحمل الديون، والوسائل الأكثر فعالية لتخفيض الديون إلى مستويات مستدامة. ولذا فإناه ينبغي النظر إلى ضبط الميزانية على أنه فرصة لخلق مزايا اقتصادية من الاحتياج المالي، وليس لتسييسه من قبل السياسيين

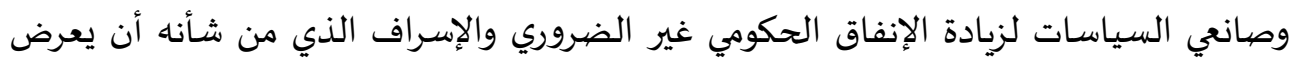
الدول إلى درجات أعلى من الضعف الاقيات لـادهادي.

الكلمات الدّالة: تمويل العجز، عجز الميزانية، الإنفاق الحكومي، الدمج المالي. تصنيف E62, H30, H50, H62, H63 :JEL تصنيف KAUJE: 